\title{
手術部位感染サーベイランスデータの評価と分析
}

手術部位感染サーベイランスは本シリーズ第 6 回において取り上げたデバイス関連感染サーベイランスと は異なり，(1) 分子デー夕に相当する手術部位感染の発生者数が比較的多い, (2) 手術手技別に実施されるた め分母デー夕に相当する手術件数が比較的少ない，(3) 手術部位感染のリスク因子情報をサーベイランスに おいて収集しているためリスク調整が可能である，といった特徴を有している。手術部位感染の発生者数が 比較的多いことから, 適切な対策を講じることができた場合, 改善の余地が大きい. 一方, 改善を定量的に 評価する際には，手術件数がさほど多くないなかで，複数のリスク因子を調整しなければならないため，患 者重症度の補正方法の選択が重要となる. 本邦においては, リスクインデックスを用いた層別解析を中心と した患者重症度補正を行っている。

本稿では，代表的な患者重症度補正手法である(1)層別化と(2)標準化について，各手法の実施方法や課題な どを解説し, 手術部位感染サーベイランスデータを用いた評価・分析方法について紹介する.

福田 治久（九州大学大学院医学研究院）

\section{1. 手術部位感染サーベイランスデータとは}

\section{1) JHAIS}

日本環境感染学会が実施している JHAIS (Japanese Healthcare Associated Infections Surveillance) は, 1999 年に旧称の JNIS (Japanese Nosocomial Infections Surveillance）として設立された。その目的 は，本邦独自のSSI サーベイランスシステムを構築し，

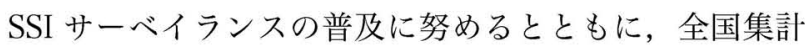
を行ってわが国の標準值を提示することである. JHAIS は，(1)手術部位感染サーベイランス部門と(2)医療器具関 連感染サーベイランスの 2 部門から構成されている。手 術部位感染サーベイランス部門は，2014 年 2 月時点で, 68 施設が参加している。後述する厚生労㗢省院内感染対 策サーベイランス事業 (JANIS) との整合性を保ちながら 運営されている.

\section{2) JANIS}

院内感染サーベイランス事業（JANIS）は，2000 年 7 月から開始された厚生労働省の事業であり, 統計法に基 づく国の統計調査（政府統計）に指定されている。2014 年 5 月現在, JANIS は, 手術部位感染 (SSI) 部門, 集 中治療室 (ICU) 部門, 新生児集中治療室 (NICU) 部門, 全入院患者部門，検査部門の 5 部門により構成されてい る。手術部位感染部門は手術部位感染 (SSI: Surgical Site Infection）をターゲットに定めており，2014 年 2 月時点において 589 施設が参加している. 施設自らが選 定した手術手技の全例について, 判定基準に基づいて SSI の判定を行うとともに，SSIのリスク因子に関する データを作成する。 なお, SSI の判定基準は, NNIS マ ニュアル 2004 (日本語訳は JANIS ウェブページに揭載) に準じて世界各国の医療機関で使用されている。また， SSI の発生例に対しては, SSIに関する詳細デー夕を作 成する，作成するデータの一覧を表 1 に示す.

表 1. 手術部位感染部門において作成するデーター覧（2014 年 5 月現在）

\begin{tabular}{|c|c|c|c|c|}
\hline \multicolumn{3}{|c|}{ 全手術症例に対して作成するデータ } & \multicolumn{2}{|c|}{ SSI 症例に対して作成するデータ } \\
\hline - 手術年月日 & - 手術手技 & - 緊急 & - 感染診断年月日 & - 病原体 3 \\
\hline - 患者 ID & - 手術時間 & - 埋入物 & - 感染特定部位 & - 病原体 4 \\
\hline - 年齢 & - 創分類 & - 内視鏡 & - 検体 & ・ 皮下膿瘍 \\
\hline - 性別 & - ASA & - 人工肛門造設 & - 病原体 1 & - 縫合不全 \\
\hline & & - SSI & - 病原体 2 & ・ 遺残膿瘍 \\
\hline
\end{tabular}




\section{2. 手術部位感染サーベイランスデータの 分析方法}

手術部位感染の発生は, 患者にとって心身ともに多大 な損失をもたらすと同時に, 医療機関にとっても追加的 な治療発生に伴う負担を増加させ, 治療を求める患者の 受入機会を減少させるという医療機関としての社会的使 命を達成する上での障害となる，医療関連感染を防止す る上で有効な手立てとなるのが，感染率の測定と現場へ のフィードバックである1).

図 1 は, A 病院の 2012 年度と 2013 年度の結腸手術 における手術部位感染発生率（一般的には「感染率」と いう用語が用いられているが, 手術部位感染の発生状況 は“割合”として算出されることに留意されたい）を比 較した結果を示している。この図から，A 病院の SSI 対 策が有効に働いていると解釈して良いであろうか?

図 1 から感染対策に活用可能なデータを読み取っては いけない，なぜならば，2013 年度の手術実施患者の重症 度が，2012 年度の患者に比べて, 軽症であった可能性を 排除できないためである。デー夕比較を行う上で重要な 原則として，比較相手との土俵を可能な限り同一にする ことが挙げられる. 同様にして, 自院と他院の感染率を 比較したい場合においても，2病院間で患者重症度が異 なっている可能性が高いことから, 感染率を単純比較し てはいけない，データ比較は患者重症度を補正して初め て実施可能になるものである。患者重症度を補正する代 表的な方法として(1) 層別化と(2) 標準化が提案されてい る. 手術部位感染を例に, それぞれの方法について解説 する。

1）層別化：リスクインデックスを用いた患者重 症度補正

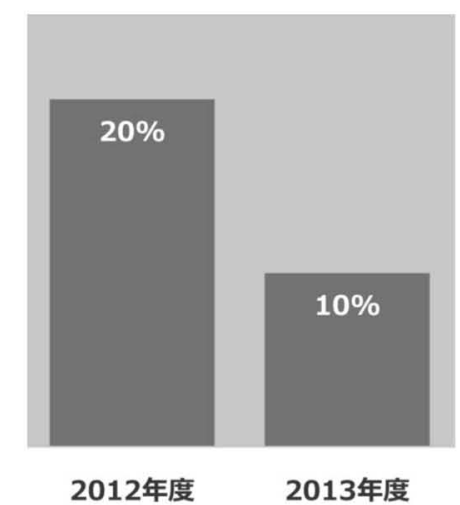

図 1. 結腸手術における手術部位感染率の経年比較

手術部位感染サーベイランスにおいて収集・提出され ている変数には, (1)「ASA」, (2)「創分類」, (3)「手術時 間」, (4)「内視鏡使用の有無」の 4 変数が含まれている (表 1 参照)。これら変数を用いて, 式 1 で算出される 「リスクインデックス」を患者重症度の違いを示す “層” として活用することができる。この算出式は 0 点〜 3 点 の 4 つの值をとり得るため, 4 つの層を作成可能である.

なお, 各変数の点数は表 2 に示す分類によって決めら れている。一部の術式に関しては，リスクインデックス のスコアをさらに「内視鏡使用の有無」によって層別さ れる。したがって，全ての手術実施症例は，患者重症度 に応じて 4 層（ 0 点〜 3 点の各点数別の層数）ないし 8 層 $(0$ 点 3 点の各点数別の 4 層 $\times$ 内視鏡使用有無の 2 層）のいずれかに分類されることになる.

各層に分類された患者群は, その重症度が比較的似通 つた集団であると考えることが可能になることから，患 者重症度が補正された結果と解釈することが可能になる。 評価対象者を似通った層に分類した上で，各層内におい てデー夕比較を実施する方法を層別化と呼び，手術部位

式 1.リスクインデックスの算出式

$\lceil A S A （ 0$ 点または 1 点 $) 」+「$ 創分類（ 0 点または 1 点 $) 」+\lceil$ 手術時間 $(0$ 点または 1 点 $) 」$

表 2. リスクインデックス算出のための点数分類

\begin{tabular}{|l|l|l|}
\hline & 0 点 & 1点 \\
\hline ASA & ASA1 : 標準的な健康な患者 & ASA3 : 重篤な全身症状があるが、活動不能でない患者 \\
& ASA2 : 軽い全身疾患の患者 & ASA4 : 日常生活を営めない、常に生命を脅かされている全身疾患の患者 \\
& & ASA5 : 手術の有無にかかわらず、24 時間生きることが予測できない瀕死の患者 \\
& & ASA6 : 脳死状態 \\
\hline 創分類 & C : 清潔創 (クラス I ) & CO : 污染創 (クラスII ) \\
& CC : 準清潔創 (クラス I ) & D : 化膿創 (クラスIV) \\
\hline 手術時間 & カットオフポイント以内 & カットオフポイント超過 \\
\hline
\end{tabular}

(出典) JANIS 年報 
図 2. リスクインデックスで層別化した 2012 年度と 2013 年度の手術部位感染発生率の比較

\begin{tabular}{|c|c|c|c|c|c|c|c|c|}
\hline & \multicolumn{3}{|c|}{ リスクインデックス：0 } & \multirow[b]{2}{*}{$\cdots \cdots$} & & \multicolumn{3}{|c|}{ リスクインデックス : 3} \\
\hline & SSI あり & SSI なし & 手術件数 & & & SSI あり & SSI なし & 手術件数 \\
\hline 2012 年度 & $a_{0}$ & $\mathrm{~b}_{0}$ & $\mathrm{a}_{0}+\mathrm{b}_{0}$ & & 2012 年度 & $a_{3}$ & $b_{3}$ & $a_{3}+b_{3}$ \\
\hline 2013 年度 & $\mathrm{C}_{0}$ & $\mathrm{~d}_{0}$ & $\mathrm{c}_{0}+\mathrm{d}_{0}$ & & 2013 年度 & $C_{3}$ & $d_{3}$ & $\mathrm{c}_{3}+\mathrm{d}_{3}$ \\
\hline
\end{tabular}

式 2. 手術部位感染率の算出式

\section{《2012年度》}

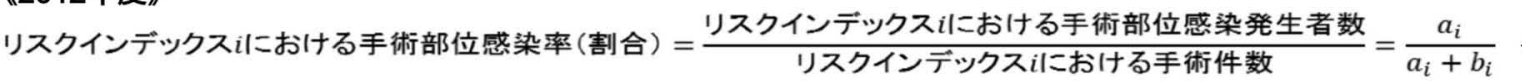
《2013年度》 リスクインデックス $i$ リおける手術部位感染率 $\left(\right.$ 割合) $=\frac{\text { リスクインデックス } i \text { における手術部位感染発生者数 }}{\text { リスクインデックス } i \text { における手術件数 }}=\frac{c_{i}}{c_{i}+d_{i}}<$

表 3. 標準化感染比の算出に必要なデータ

\begin{tabular}{|c|c|}
\hline & 観察集団の感染者数 \\
\hline (2) & 観察集団のリスクインデックス別手術件数 \\
\hline (3) & 観察集団のリスクインデックス別感染率 \\
\hline
\end{tabular}

感染領域ではリスクインデックスに基づいて層を形成し て患者重症度の補正を試みている。症例を重症度（リス クインデックス）に応じて層別化することによって，各 層における，「2012 年度と 2013 年度の手術部位感染発 生率の比較」や「自院と他院の感染率の比較」が初めて 意味をもつことになる (図 2).JANIS では各層におけ る手術部位感染率を公開していることから，自院におけ る症例を対象にした層別感染率と JANIS 平均との比較 が可能になる。また, 自院の前年度の層別感染率と今年 度の層別感染率を比較することも可能になる. なお, 手 術部位感染発生率は式 2 の計算式を用いて算出する.

2）間接標準化法：期待感染者数の算出にリスク インデックスを用いた場合

リスクインデックスに応じて層別して手術部位感染発 生率を算出することは，患者重症度を簡便に補正できる という利点があるものの, 問題点がないわけではない. 第 1 の問題点は, 手術件数が十分に実施されていない医 療機関においては, 手術実施症例を 4 層ないし 8 層に分 類した結果, 各層における手術件数が少なくなってしまう. 仮に年間 100 件の結腸手術を実施している医療機関であ っても, 4 層に分類した結果, 各層の平均患者数は 25 件になってしまう。そその場合，1例の感染者が発生して
いる場合の感染率は 4\%, 2 例では $8 \%, 3$ 例では $12 \%$ と なり, 感染者 1 例の増加で, 感染率が $4 \%$ も変化し, 感 染率の值が不安定になってしまう。

第 2 の問題点は, 手術部位感染率はリスクインデック ス分類の数だけ算出されるため, 病院全体としての手術 部位感染発生率が, 前年度や他院と比べて優れているか ぞうかを判断することが難しくなる。あるリスクインデ ックスにおいては前年度よりも優れていたとしても，他 のリスクインデックスにおいては前年度より劣っていた 場合, 病院全体としてのパフォーマンスを解釈すること ができなくなるおそれがある。

こうした問題点への対応策として使用されているのが, 標準化感染比 (SIR : Standardized Infection Ratio) である. 標準化感染比は, 間接標準化法という 患者重症度補正手法を手術部位感染に適用したものであ る脚注 1. 公衆衛生領域においては, 標準化死亡比 （SMR：Standardized Mortality Ratio）が広く活用さ れている，標準化感染比は，自院における層別感染率を 使用する必要がなく, また, 手術部位感染発生率の状況 を 1 指標によって表現できるため, 症例数の問題や解釈 の問題に対する有効な解決策の 1 つになり得る。この標 準化感染比は, JHAIS においても報告されている. 標準化感染比の算出に必要となるデータを表 3 に示す.

脚注 1 標準化には直接法と間接法の 2 つの方法がある。一般的に観察集団の人口規模が大きい場合は直接法を，小さい場合は間接 法を用いる，手術部位感染領域においては，観察集団の人口規模が小さいため，間接法が適切であると考元られる

$$
-233-
$$


表 4. 標準化感染比算出のための手順

\begin{tabular}{|c|c|}
\hline ステップ & 作業内容 \\
\hline ステップ 1 & $\begin{array}{l}\text { A 列にリスクインデックスを入カ } \\
\text { B 列の合計欄に自院における手術部位感染発生者数（O）を入力 } \\
\text { C 列に自院における手術実施件数を入力 } \\
\text { D 列に JANIS における手術部位感染発生者数を入力 } \\
\text { E 列に JANIS における手術件数を入力 }\end{array}$ \\
\hline ステップ 2 & F 列に期待感染者数を算出. その際，G 列に示した算出式（エクセルにおいて使用可能）を用いる. \\
\hline ステップ 3 & F6 に期待感染者数の合計值（E）を算出．その際，G6 に示した算出式を用いる. \\
\hline ステップ 4 & B9 に標準化感染比を算出. その際，B10 に示した算出式を用いる. \\
\hline ステップ 5 & D9 およびF9 に標準化感染比の 95\%信頼区間を算出. その際，D10 およびF10 に示した算出式を用いる. \\
\hline
\end{tabular}

図 3. 標準化感染比算出のための手順

\begin{tabular}{|c|c|c|c|c|c|c|c|}
\hline & A & B & C & D & E & $\mathbf{F}$ & G \\
\hline 1 & リスクインデックス & 観察集団の感染者数 & 観察集団の手術件数 & 基愺集団の感染者数 & 基準集团の手術件数 & 期待感染者数 & 期待感染者数計算式 \\
\hline 2 & 0 & & 100 & 1,191 & 11,308 & 10.53 & $=\mathrm{C} 2 *(\mathrm{D} 2 / \mathrm{E} 2)$ \\
\hline 3 & 1 & & 70 & 1,129 & 7,774 & 10.17 & $=\mathrm{C} 3 *(\mathrm{D} 3 / \mathrm{E} 3)$ \\
\hline 4 & 2 & & 20 & 500 & 1,839 & 5.44 & $=\mathrm{C} 4 *(\mathrm{D} 4 / \mathrm{E} 4)$ \\
\hline 5 & 3 & & 10 & 62 & 142 & 4.37 & $=\mathrm{C} 5 *(\mathrm{D} 5 / \mathrm{E} 5)$ \\
\hline 6 & 合計 & 20 & & & & 30.51 & $=S U M(F 2: F 5)$ \\
\hline 7 & & & & & & & \\
\hline 8 & & \multicolumn{2}{|c|}{ 標準化感染比（SIR） } & \multicolumn{2}{|c|}{ 95\%信頼区間 : 下限 } & \multicolumn{2}{|c|}{ 95\%信頼区間：上限 } \\
\hline 9 & 算出値 & 0.66 & & 0.37 & & 0.94 & \\
\hline 10 & 算出式 & $=\mathrm{B} 6 / \mathrm{F} 6$ & & \multicolumn{2}{|c|}{$=\mathrm{B} 9-1.96 *(\mathrm{~B} 9 / \mathrm{F} 6)^{\wedge} 0.5$} & \multicolumn{2}{|c|}{$=\mathrm{B} 9-1.96 *(\mathrm{~B} 9 / \mathrm{F} 6)^{\wedge} 0.5$} \\
\hline
\end{tabular}

観察集団はA 病院における結腸手術（COLO）のデータを想定した.

基準集団は JANIS2012 年年報の結腸手術（COLO）のデータを使用した.

r(1)観察集団の実際の感染者数」および「(2)観察集団 のリスクインデックス別手術件数」は，観察集団を“A 病院における B 手術” とすれば，手術部位感染サーベイ ランスを実施している医療機関は把握可能である。「(3)基 準值のリスクインデックス別感染率」は，基準集団を “2012 年度 JANIS 全体におけるB 手術”とすれば, JANIS 年報から把握可能である。一方，基準集団を“自 院の前年度以前” とするのであれば自院の過去のサーベ イランスデータを使用することになる。

自院における 2012 年度の結腸手術を観察対象集団, JANIS 全体における 2012 年度の結腸手術を基準集団と した場合の, 標準化感染比の算出手順を表 4 に示し, エ
クセル画面に見立てた数值例を図 3 に示す.

ステップ 1 は, 手術部位感染サーベイランスにおいて 収集したデータをリスクインデックス別に入力する作業 である，標準化感染比を算出する際には，自院のリスク インデックス別感染者数データは不要であり, 総感染者 数（O：Observed）のみが必要となる．ステップ 2 においてリスクインデックス別の期待感染者数（E：

Expected）を算出する．期待感染者数とは，自院にお けるリスクインデックス別の手術部位感染の発生リスク が JANIS 全体におけるリスクインデックス別の手術部 位感染発生リスクと同等であった場合，自院において発 生すると期待（推測）される感染者数である．基準集団 
式 3. 標準化感染比の算出式

$$
\text { 標準化感染比 }(\mathrm{SIR})=\frac{\text { 実際の感染者数の合計値 }(O)}{\text { 期待感染者数の合計値 }(E)}=\frac{O}{\sum_{i=1}^{n}\left(R_{i} \times P_{i}\right)}
$$

式 4. 標準化感染比の 95\%信頼区間の算出式

$$
\begin{aligned}
& 95 \% \text { 信頼区間下限 }=S I R-1.96 \times \sqrt{\frac{S I R}{\text { 期待感染者数 }(E)}} \\
& 95 \% \text { 信頼区間上限 }=S I R+1.96 \times \sqrt{\frac{S I R}{\text { 期待感染者数 }(E)}}
\end{aligned}
$$

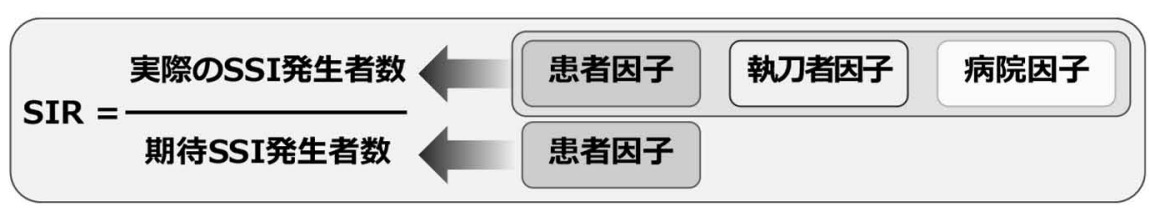

図 4. 標準化感染比の算出式の直感的理解

における発生リスクを観察集団における患者数を乗ずる ことで算出される（図３の G 列参照）、ステップ 3 はリ スクインデックス別の期待感染者数の合計值を算出する. なお，期待感染者数が 10 未満である場合，標準化感染 比の算出は好ましくないとされている。 ステップ4 にお いて標準化感染比を算出する，標準化感染比は式 3 で与 えられる，ただし， $\mathrm{i}$ は各層を， $\mathrm{n}$ は層の総数を， $\mathrm{R}$ は基 準集団における手術部位感染発生リスクを，P は観察集 団に拄ける手術件数である. 最後に，ステップ5として, 標準化感染比の 95\%信頼区間を算出する．算出式は式 4 のと抢りである.

上記の手順によって算出された標準化感染比を解粕する ことは容易である．標準化感染比の分母は, A 病院が JANIS 全体と同じ環境下であれば発生したであろう感染者 数を示しており, 分子は $\mathrm{A}$ 病院自身の実績を示している. したがって，標準化感染比の值が 1 を上回った場合，A 病院が JANIS 全体と同じ環境下であ扎ば発生したであ ろう感染者数よりも, A 病院自身の実際の感染者数が多 いことを意味し, $\mathrm{A}$ 病院は JANIS 平均よりもパフォー マンスが低いと解釈することができる。一方，標準化感 染比の值が 1 を下回った場合, A 病院が JANIS 全体と 同じ環境下であ机ば発生したであろう感染者数よりも， $\mathrm{A}$ 病院自身の実際の感染者数が少ないことを意味するた め, A 病院は JANIS 平均よりもパフォーマンスが高いと 解釈できる，標準化感染比が 1 の場合, A 病院は JANIS
平均と同様のパフォーマンスであると解釈できる.

この標準化感染比の解釈方法に関する直感的イメージ は図 4 を参考にされたい. 分母の期待感染者数は患者側 の要因だけで推測される感染者数を推定しているもので ある. 一方, 分子の実際の感染者数は, 患者側要因に加 え, 執刀者側の要因や病院側の要因が含まれている. 分 子が分母よりも小さい值を示す場合（標準化感染比が 1 未満), 執刀者因子や病院因子が手術部位感染発生を抑 制する方向に作用していることが期待され，A病院の パフォーマンスが優れていると解釈することが可能にな る. 統計学的に有意に優れているかどうかを判断するた めには，標準化感染比の 95\%信頼区間の值を用いる. 図 3 では, 標準化感染比が 0.66 で, 95\%信頼区間が 0.37 〜 0.94 であり, 95\%信頼区間が 1.00 をまたいでいない. このような時, 観察集団は基準集団よりも統計学的に標 準化感染比が低いと解釈することができる。一方, 標準 化感染比の 95\%信頼区間が 1.00 以上の場合, 観察集団 は基準集団よりも統計学的に SIR が高いと解釈される.

上記の例は, 標準化感染比の基準集団として JANIS 平均を用いたが, 基準集団として自院の数年分のデータ を設定すれば自院の過去との比較が可能となる。

3）間接標準化法: 期待感染者数の算出にロジス ティック回帰モデルを用いた場合

標準化感染比は, 従来のリスクインデックス別の層別 
表 5. 患者重症度調整モデル別の多変量ロジスティック回帰分析の推定結果

\begin{tabular}{|c|c|c|c|c|c|c|}
\hline & \multicolumn{2}{|c|}{$\operatorname{APPY}(n=3,238)$} & \multicolumn{2}{|c|}{ BILI $^{+}(n=3,184)$} & \multicolumn{2}{|c|}{$\mathrm{CHOL}(n=6,177)$} \\
\hline & RI モデル & ALL モデル & RI モデル & ALL モデル & RI モデル & ALL モデル \\
\hline \multicolumn{7}{|l|}{ 共変量 } \\
\hline 創分類 : 污染創/化膿創 & $3.4(2.4-4.8)$ & $3.5(2.5-5.0)$ & $3.3(2.0-5.3)$ & $2.9(1.7-5)$ & $2.9(2.0-4.2)$ & $2.9(1.9-4.4)$ \\
\hline ASA : 3-6 & $2.5(1.5-4.2)$ & $2.1(1.2-3.7)$ & $1.1(0.8-1.4)$ & $1.0(0.7-1.3)$ & $1.2(0.8-1.8)$ & $1.0(0.6-1.5)$ \\
\hline 手術時間 : カットオフ以上 & $4.5(3.0-6.8)$ & & $3.0(2.4-3.9)$ & & $3.1(2.2-4.4)$ & \\
\hline 手術時間 : 連続变数 & & $1.9(1.6-2.4)$ & & $1.2(1.2-1.3)$ & & $1.4(1.3-1.6)$ \\
\hline 内視鏡 : なし & $1.5(1.1-2.2)$ & $1.5(1.0-2.2)$ & & & $3.8(2.8-5.3)$ & $2.9(2.1-4.1)$ \\
\hline 緊急手術 : あり & & $1.2(0.7-2.1)$ & & $1.9(1.0-3.7)$ & & $0.9(0.5-1.4)$ \\
\hline 全身麻酥：あり & & $1.4(0.9-2.4)$ & & $0.6(0.3-1.4)$ & & $0.8(0.1-7.1)$ \\
\hline 外傷 : あり & & n.a. & & $0.7(0.1-6.0)$ & & n.a. \\
\hline 埋入物：あり & & $2.0(0.4-9.3)$ & & $0.4(0.1-3.1)$ & & $1.0(0.3-3.4)$ \\
\hline 人工肛門 : あり & & n.a. & & $1.8(0.5-6.5)$ & & $1.2(0.3-5.1)$ \\
\hline 性別 : 女性 & & $0.8(0.6-1.1)$ & & $0.9(0.7-1.1)$ & & $0.5(0.4-0.8)$ \\
\hline 年齢 : 10 歳 & & $1.1(0.99-1.2)$ & & $1.0(0.9-1.1)$ & & $1.4(1.2-1.6)$ \\
\hline \multirow[t]{3}{*}{ c-index } & 0.781 & 0.784 & 0.63 & $0.69 *$ & 0.78 & $0.81 *$ \\
\hline & \multicolumn{2}{|c|}{$\operatorname{COLN}(n=11,545)$} & \multicolumn{2}{|c|}{ GAST $(n=8,478)$} & \multicolumn{2}{|c|}{$\operatorname{REC}(n=4,629)$} \\
\hline & RI モデル & ALL モデル & RI モデル & ALL モデル & RI モデル & ALL モデル \\
\hline \multicolumn{7}{|l|}{ 共变量 } \\
\hline 創分類 : 污染創/化膿創 & $2.9(2.6-3.4)$ & $2.6(2.2-3.1)$ & $3.3(2.5-4.5)$ & $2.6(1.8-3.8)$ & $2.3(1.8-3.0)$ & $2.4(1.7-3.2)$ \\
\hline ASA : 3-6 & $1.4(1.2-1.6)$ & $1.3(1.2-1.5)$ & $1.4(1.1-1.7)$ & $1.3(1.0-1.6)$ & $1.1(0.9-1.4)$ & $1.1(0.8-1.4)$ \\
\hline 手術時間 : カットオフ以上 & $1.5(1.4-1.7)$ & & $1.9(1.5-2.3)$ & & $2.3(1.9-2.8)$ & \\
\hline 手術時間 : 連続变数 & & $1.2(1.2-1.2)$ & & $1.3(1.3-1.4)$ & & $1.2(1.1-1.2)$ \\
\hline 内視鏡 : なし & $2.2(1.9-2.5)$ & $2.2(1.9-2.5)$ & $2.1(1.7-2.6)$ & $2.3(1.8-2.9)$ & $2.2(1.8-2.7)$ & $2.0(1.6-2.5)$ \\
\hline 㗨急手術 : あり & & $1.2(0.99-1.4)$ & & $1.9(1.3-2.7)$ & & $0.9(0.6-1.2)$ \\
\hline 全身麻酥 : あり & & $1.3(0.6-2.9)$ & & $0.5(0.2-1.2)$ & & $6.7(1.6-27.5)$ \\
\hline 外偒：あり & & $1.3(0.6-2.8)$ & & $2.7(0.5-13.7)$ & & $0.5(0.1-3.6)$ \\
\hline 埋入物：あり & & $0.4(0.2-0.8)$ & & $1.2(0.5-2.8)$ & & $0.8(0.3-1.8)$ \\
\hline 人工肛門 : あり & & $1.2(1.0-1.4)$ & & $1.3(0.6-3.1)$ & & $1.3(1.1-1.6)$ \\
\hline 性別：女性 & & $0.9(0.8-1.1)$ & & $0.7(0.6-0.8)$ & & $0.8(0.7-0.95)$ \\
\hline 年齢 : 10 歳 & & $1.0(0.97-1.0)$ & & $1.1(1.0-1.2)$ & & $1.0(0.9-1.0)$ \\
\hline$c$-index & 0.66 & $0.67 *$ & 0.62 & $0.68 *$ & 0.63 & $0.68 *$ \\
\hline
\end{tabular}

[出典] 福田 2013 を改変

各共变量における表中の值はオッズ比（95\%信頼区間）を示す.

RI モデル ; リスクインデックスによる層別解析と同様のリスク因子を用いたモデル

ALL モデル ; SSI サーベイランスの収集变数の全てを用いたモデル

* : RI モデルの c-index vs. ALL モデルの c-index の DeLong test において有意差を認めたもの

太字 ; 有意水準 $5 \%$ におてて有意差を認めたもの

n.a. : 「外傷あり」「人工肛門あり」の全ての症例において SSIが発生していなかったため, 推定モデルから除外

† BILI はNNIS リスクインデックスに内視鏡の有無が使用されていないため, RI モデルおよび ALL モデルの共変量から内視鏡の有無は使用しなかった. 


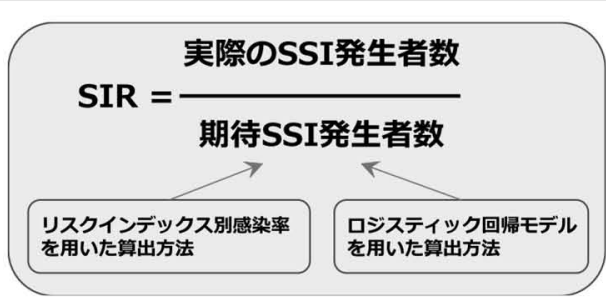

図 5. 標準化感染比における期待感染者数（分母データ）の算出方法

比較の限界点を克服する 1 つの解決策であるものの, 米 国 NHSN は，1）のリスクインデックスを用いた層別化 から決別しロジスティック回帰モデルを用いた標準化感 染比へと移行している。ここで注意をしなければならな いのは，米国 NHSN が使用する標準化感染比は，2）の JHAIS でも使用されている標準化感染比とは算出方法が 異なることである. 米国 NHSN がリスクインデックス から決別した理由は明らかではないが，リスクインデッ クスはその值の妥当性に関する疑義が複数の論文 ${ }^{2-7}$ に よって指摘されていることと無縁ではないと考えられる. リスクインデックスに対する疑義として以下のようなも のがある：

I .リスクインデックスは, 「ASA3〜6」, 「污染創・化 膿創」,「手術時間がカットオフポイント超過」の該 当件数から算出されるものの，これらは 1 点という 同じ重み付けを用いることは適切なのか?

II . リスクインデックスの算出式が, 全ての術式で同じ であることは適切なのか？

III. 手術部位感染サーベイランスでは, 「緊急手術」や 「年齢」,「埋入物有無」といった他の変数を収集し ているものの, これら変数を用いないことは適切な のか?

IV.「創分類」や「ASA」は 4 值および 6 值の值を収集 しているものの， 0 点と 1 点に 2 值に分類すること は適切なのか?

日本の 24 〜 35 病院から収集した JANIS データを 用いた先行研究においても，上記と同じ疑義が生じて いる ${ }^{8)}$. 表 5 は, 各手術手技における手術部位感染の リスク因子を明らかにするために実施した多変量ロジ スティック回帰分析の推定結果を示している.上述のI が妥当性をもつためには, 各リスク因子のオッズ比は同 様の值にならなければならない.しかし, 実際には各リ スク因子のオッズ比は異なっていた．IIが妥当性を持つ ためには，各手術手技間のリスク因子別のオッズ比は同 様の值にならなければならない.しかし, 実際には術式
によってリスク因子が異なっていた．IIIが妥当性をもつ ためには, リスクインデックスに使用されている変数の みで調整したモデルと手術部位感染サーベイランスで収 集されている全変数で調整したモデルの間に予測能に差 がないはずである。しかし，実際には手術部位感染サー ベイランスで収集されている全変数で調整したモデルを 用いた方が手術部位感染の予測能が統計学的に有意に高 かった。ただし, IVについては, 表 5 において確認でき ていないものの, 検討する余地は大きいと考えられる.

このリスクインデックスの問題に対する解決策の 1 つ が，ロジスティック回帰モデルを用いた標準化感染比の 算出である. 図 5 に示すように，2）において紹介した 標準化感染比の場合, 分母の期待感染者数はリスクイン デックスを基準にして算出しているが，この期待感染者 数はロジスティック回帰モデルを用いて算出することが できる（分子の「実際の感染者数」に変更はない）， Mu らは, NHSN の手術部位感染サーベイランスデータを用 いて, 期待感染者数を予測するモデルを術式別に開発し, 当該モデルを用いた期待感染者数によって標準化感染比 を算出可能な環境を構築している ${ }^{9)}$. 日本のデータにつ いては既に述べたが, 米国の NHSN のデータを用いた 検証においても，新たに提案されたロジスティック回帰 モデルを活用したモデルはリスクインデックスを活用し たモデルよりも，期待感染者数をより適切に算出できる ことが確認されている ${ }^{9)}$. なお，ロジスティック回帰分 析については, 本シリーズ第 8 回 (本号揭載)において 解説する.

\section{3. 標準化感染比を用いた感染対策の有効 性評価}

これまで述べてきたように, 自院の手術部位感染のパ フォーマンスを評価するためには, リスクインデックス を用いた層別化よりも標準化が適していると考えられる。 標準化算出に使用する期待感染者数（分母）データは, ロジスティック回帰モデルを用いた推定が望ましいもの の, 本邦では米国 NHSN と異なり, JANIS データを基 


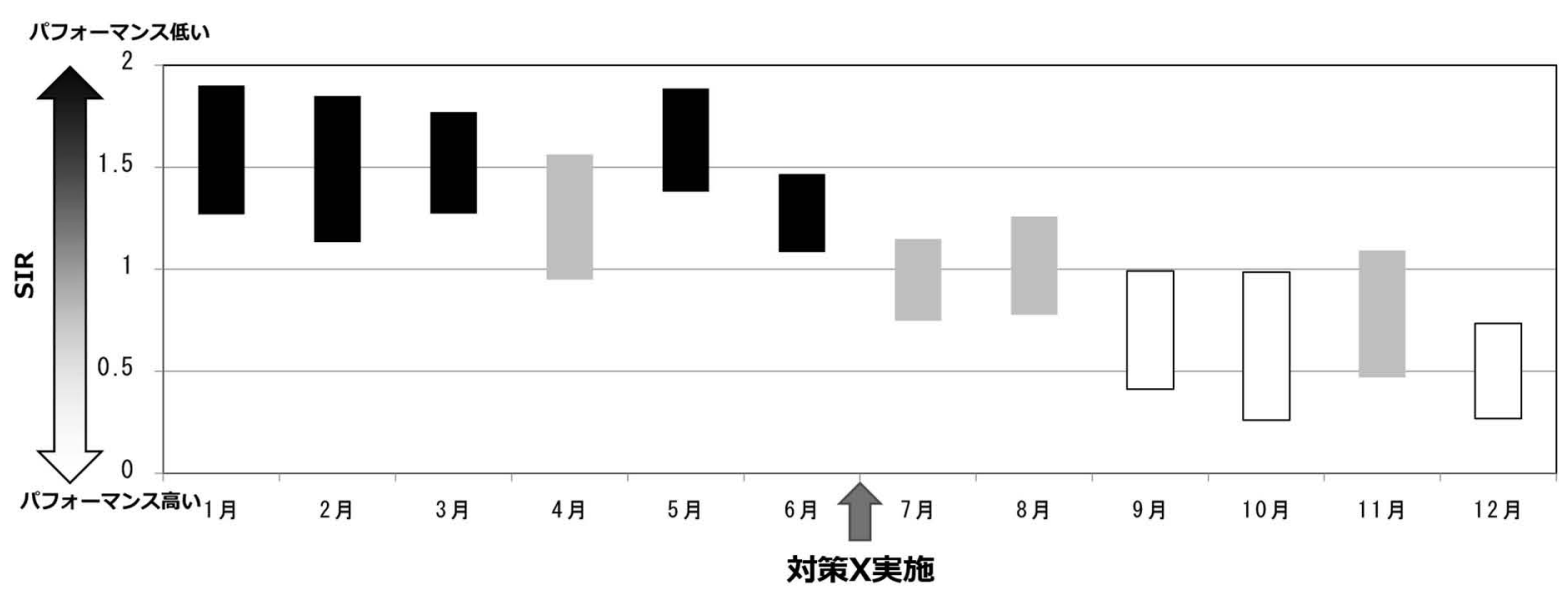

図 6. 時期別の標準化感染比の推移

準集団と定めた期待感染者数を算出するためのモデルが 構築されていないことから, リスクインデックスを用い た方法だけを使用することができる．もちろん，自院の 過去データを基準集団と定めた場合, 各施設担当者が自 ら期待感染者数を算出するためのモデルを開発すること は可能である。本節では，前節と同様に，JANIS データ を基準集団と定めた標準化感染比の活用方法について紹 介する。

標準化感染比の有用な活用方法は, 自院の手術部位感 染対策が正しい方向へ進んでいるかどうかを評価するた めに使用することである. そのためには, 自院の時期別 の標準化感染比を算出し, 標準化感染比のトレンドを評 価する必要がある。時期別の標準化感染比を算出するた めには，観察集団を自院の時期別集団に設定すれば良い. この時, 注意しなければならないことは, 時期を月単位 などへ細分化しすぎることである。期待感染者数が 10 件に満たない場合は, 当該期間における標準化感染比の 值の安定性が損なわれるおそれがあるためである。施設 規模によって判断は異なるが，月単位での算出において 期待感染者数が 10 件を下回る場合は, 四半期別や半期 別といつた単位に再設定することを推奨する。標準化感 染比ではなく, 手術部位感染率を用いた場合, 時期によ って患者重症度が異なると考えられるため, 単純な手術 部位感染率の推移を見たとしても, それが患者重症度の 違いによるものなのか, 感染対策の成否によるものなの かを識別することができない. しかし, 標準化感染比の 推移を見ることで, 患者重症度の違いを完全に調整でき ているとはいえないものの, 感染率を用いるよりも一層 適切に感染対策の成否を評価することが可能になる。

図 6 は，A 病院における月別の標準化感染比の 95\% 信頼区間を算出した結果を示している. 図 6 のように各
月の標準化感染比が減少傾向にあれば, $\mathrm{A}$ 病院の感染対 策が良い方向に進んでいることを判断できる。また，A 病院において 6 月末に対策 X を実施している場合，対策 $\mathrm{X}$ の有効性の評価も実施可能である. この場合, $1 \sim 6$ 月の標準化感染比の平均值が 1.46 であり, 7 〜 12 月の 標準化感染比の平均值が 0.76 となることから， 2 群間 の差についての検定を実施することで，評価が可能とな る。ただし，この事例の場合，評価月のサンプルが少な いことに留意すべきである.

\section{おわりに}

本稿では, 手術部位感染サーベイランスに焦点を当て て, サーベイランスデータを用いて, 自院のパフォーマ ンスを評価するための手法について解説した。 また，標 準化感染比を用いた感染対策の有効性評価の事例につい ても紹介した。標準化感染比は, 手術部位感染に限らず, デバイスサーベイランスにおいても使用可能な指標であ り，米国 NHSN においても使用されている。本邦にお いては, 今のところ, ロジスティック回帰分析を用いた 標準化感染比の算出モデルが公開されていないが, 算出 モデルは著者らが開発しているところであり, 近々利用 できる見込みである。 なお, ロジスティック回帰分析に ついては, 本号揭載の本シリーズ第 8 回で取り上げてい るため, そちらを参考にしていただきたい.

参考文献

1) Gaynes R, Richards C, Edwards J, et al. Feeding back surveillance data to prevent hospital-acquired infections. Emerg Infect Dis 2001;7:295-298.

2) Geubbels EL, Mintjes-de Groot AJ, van den Berg JM, et al. An operating surveillance system of surgical- 
site infections in The Netherlands Infect Control Hosp Epidemiol 2000;21:31 1-318.

3) Brandt C, Hansen S, Sohr D, et al. Finding a method for optimizing risk adjustment when comparing surgical-site infection rates. Infect Control Hosp Epidemiol 2004;25:313-318.

4) Geubbels EL, Grobbee DE, Vandenbroucke-Grauls $\mathrm{CM}$, et al. Improved risk adjustment for comparison of surgical site infection rates. Infect Control Hosp Epidemiol 2006;27:1330-1339.

5) Friedman ND, Bull AL, Russo PL, et al. Performance of the national nosocomial infections surveillance risk index in predicting surgical site infection in australia. Infect Control Hosp Epidemiol 2007;28:5559.

6) Chen LF, Anderson DJ, Kaye KS, et al. Validating a 3-point prediction rule for surgical site infection after coronary artery bypass surgery. Infect Control Hosp Epidemiol 2010;31:64-68.

7) Roy MC, Herwaldt LA, Embrey R, et al. Does the Centers for Disease Control's NNIS system risk index stratify patients undergoing cardiothoracic operations by their risk of surgical-site infection? Infect Control Hosp Epidemiol 2000;21:186-190.

8) 福田治久. 手術部位感染発生率の病院間比較手法の検 証：JANIS デー夕を用いた全国多施設研究. 環境感染 誌 2013; 28: 63-73.

9) $\mathrm{Mu}$ Y, Edwards JR, Horan TC, et al. Improving riskadjusted measures of surgical site infection for the national healthcare safety network. Infect Control Hosp Epidemiol 2011;32:970-986. 